\title{
Pharmacogenetics of anticancer monoclonal antibodies
}

\author{
Dmitrii Shek ${ }^{1}$, Scott A. Read ${ }^{1,2}$, Golo Ahlenstiel ${ }^{1,2,3}$, Irina Piatkov ${ }^{3}$ \\ 'Blacktown Clinical School, Western Sydney University, Blacktown, NSW 2148, Australia. \\ ${ }^{2}$ Storr Liver Centre, The Westmead Institute for Medical Research, The University of Sydney, Westmead, NSW 2145, \\ Australia. \\ ${ }^{3}$ Blacktown Hospital, Blacktown, NSW 2148, Australia.
}

Correspondence to: Dr. Irina Piatkov, Blacktown Hospital, Blacktown, NSW 2148, Australia.

E-mail: irina.piatkov@health.nsw.gov.au

How to cite this article: Shek D, Read SA, Ahlenstiel G, Piatkov I. Pharmacogenetics of anticancer monoclonal antibodies. Cancer Drug Resist2019;2:69-81. http://dx.doi.org/10.20517/cdr.2018.20

Received: 31 Oct 2018 First Decision: 11 Nov 2018 Revised: 9 Jan 2019 Accepted: 19 Feb 2019 Published: 19 Mar 2019

Science Editor: Enrico Mini Copy Editor: Cai-Hong Wang Production Editor: Huan-Liang Wu

\begin{abstract}
Pharmacogenetics is the study of therapeutic and adverse responses to drugs based on an individual's genetic background. Monoclonal antibodies (mAbs) are a rapidly evolving field in cancer therapy, however a number of newly developed and highly effective mAbs (e.g., anti-CTLA-4 and anti-PD-1) possess pharmacogenomic profiles that remain largely undefined. Since the first chemotherapeutic mAb Rituximab was approved in 1997 by the US Food and Drug Administration for cancer treatment, a broad number of other mAbs have been successfully developed and implemented into oncological practice. Nowadays, mAbs are considered as one of the most promising new approaches for cancer treatment. The efficacy of mAb treatment can however be significantly affected by genetic background, where genes responsible for antibody presentation and metabolism, for example, can seriously affect patient outcome. This review will focus on current anticancer mAb treatments, patient genetics that shape their efficacy, and the molecular pathways that bridge the two.
\end{abstract}

Keywords: Pharmacogenetics, pharmacogenomics, immune-checkpoint proteins, monoclonal antibodies, cancer immunotherapy, personalized medicine

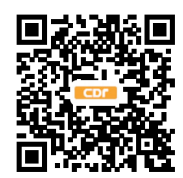




\section{INTRODUCTION}

\section{The evolution of monoclonal antibodies in cancer treatment}

Over the last 20 years, immunotherapy has become established as one of the most promising and effective therapeutic strategies targeting cancer. Monoclonal antibodies (mAbs) in particular have revolutionized the treatment of hematologic and solid malignancies ${ }^{[1]}$. In 1997, the first chemotherapeutic mAb (Rituximab) was approved by the FDA for clinical use ${ }^{[2]}$, and was quickly followed by numerous other mAbs for a range of malignancies [Table 1]. The generation of therapeutic $\mathrm{mAbs}$ began over 20 years previous, where the first mAbs were synthesized using hybridoma technologies from murine sources (-omab). The method consisted of mouse immunisation against a specific antigenic epitope, followed by extraction of splenic B-lymphocytes and their fusion with immortal myeloma cells. The resulting cell clones produced antibodies towards a single epitope, hence the name monoclonal (single clone) antibodies. Unfortunately, the use of such mAbs was restricted due to the development of an immune response against the mouse derived antibodies, termed HAMA (human anti-mouse antibody response) ${ }^{[3]}$. The development of mAbs has since evolved quickly, resulting in subsequent generations of $\mathrm{mAbs}$ that were chimeric (-ximab), humanised (-zumab) and fully human (-umab). Chimeric mAbs are composed of variable regions derived from mice, and the remainder [constant domains of heavy chain $-\mathrm{C}_{\mathrm{H}(1-3)}$ ] from human or other animals. Humanised mAbs are engineered from human sources and contain only a mouse derived antigen-binding fragment representing $\sim 5 \%$ of the $\mathrm{mAb}$. Human mAbs are the gold standard, and are generated from hybridomas of human or humanised mouse origin ${ }^{[4]}$. mAbs with the strongest affinities/biological response are selected using phage display systems $^{[5]}$, or high throughput immunoassays ${ }^{[6-8]}$.

Monoclonal antibodies have been developed to target cancer cells using a number of distinct and fascinating mechanisms. Naked antibodies that lack any type of drug conjugation work by either: (1) stimulating the immune system by binding to an antigen present on a cancer cell (alemtuzumab); (2) boosting the immune response via interaction with immune-checkpoint proteins (CTLA-4 inhibitors (ipilimumab)/ PD-1 inhibitors (pembrolizumab); or (3) blocking growth factor receptors on cancer cells (trastuzumab). In contrast, conjugated (tagged, labelled, loaded) mAbs work by carrying radioactive elements [radiolabelled antibodies - ibritumomab tiuxetan (Zevalin)] or chemotherapeutic drugs [chemolabeled antibodies brentuximab vedotin (Adcetris)]. An additional group of mAbs, called bispecific mAbs, possess two different antigen binding fragments (Fabs) whose function is to bring cells in proximity to one another. For example, blinatumomab binds $\mathrm{CD} 19$ on lymphoma cells and $\mathrm{CD} 3$ on $\mathrm{T}$ cells, thus prompting $\mathrm{T}$ cell cytotoxicity against leukemic B cells ${ }^{[\rho]}$.

\section{Adverse events and monoclonal antibody treatment}

While mAbs are a promising new therapy for the treatment of a growing number of cancers, they can cause various systemic and cutaneous adverse events, including a wide range of hypersensitivities: antibody mediated type I reactions (anaphylaxis), cytotoxic type II (neutropenia, thrombocytopenia, haemolytic anaemia), immune complex type III (vasculitis), T cell mediated type IV (delayed mucocutaneous reactions, cardiac events, progressive multifocal encephalopathy $(\mathrm{PML})^{[10]}$. Type I hypersensitivities are most common, with a recent study showing that among 901 patients treated with rituximab, $9 \%(n=79)$ faced type I hypersensitivity reactions. The absence of IgE against rituximab, however suggested that the patients developed pseudo-allergic reactions, which manifest with the same clinical symptoms as true type I hypersensitivities (flushing, hypotension, mucous secretion, rash, rhinitis, conjunctivitis) but less severe $^{[11,12]}$. Cytotoxic (type II) reactions manifest as neutropenia, anaemia, thrombocytopenia, and are common for rituximab and trastuzumab. This is perhaps due to their antitumor mechanism of action, which occurs via antibody- and complement-dependent cell cytotoxicity ${ }^{[13]}$. Type III reactions occur due to the formation of antibody-antigen complexes and are relatively rare in response to $\mathrm{mAb}$ treatment, with the exception of chimeric antibodies such as rituximab, where serum sickness-like reaction occur in up to $20 \%$ of individuals ${ }^{[14]}$. T-cell mediated type IV hypersensitivity reactions occur following cessation of $\mathrm{mAb}$ 
Table 1. Adapted list of monoclonal antibodies approved by FDA for cancer treatment

\begin{tabular}{|c|c|c|c|c|c|c|}
\hline $\begin{array}{l}\text { Active } \\
\text { ingredient }\end{array}$ & $\begin{array}{l}\text { Drug's name } \\
\text { (year of FDA } \\
\text { approval) }\end{array}$ & Indications & Structure & Company & $\begin{array}{c}\text { Mechanism of } \\
\text { action }\end{array}$ & $\begin{array}{c}\text { Important adverse } \\
\text { events }\end{array}$ \\
\hline Alemtuzumab & $\begin{array}{l}\text { Campath } \\
\text { (2001) }\end{array}$ & $\begin{array}{l}\text { CLL (chronic } \\
\text { lymphocytic } \\
\text { leukemia) }\end{array}$ & $\begin{array}{l}\text { Humanized } \\
\text { IgG1 kappa }\end{array}$ & $\begin{array}{l}\text { Genzyme } \\
\text { Corporation }\end{array}$ & $\begin{array}{l}\text { CD } 52 \text { binding, which } \\
\text { leads to antibody- } \\
\text { dependent lysis of } \\
\text { leukemic cells }\end{array}$ & $\begin{array}{l}\text { Infusion-related events } \\
\text { (bronchospasm, rash, } \\
\text { hypotension), immune- } \\
\text { mediated diseases }\end{array}$ \\
\hline Bevacizumab & Avastin (2004) & $\begin{array}{l}\text { As part of } \\
\text { combination } \\
\text { therapy for } \\
\text { metastatic } \\
\text { colorectal } \\
\text { cancer and } \\
\text { HER-2 negative } \\
\text { metastatic } \\
\text { breast cancer }\end{array}$ & $\begin{array}{l}\text { Humanized } \\
\text { lgG1 }\end{array}$ & $\begin{array}{l}\text { Genentech } \\
\text { Inc. }\end{array}$ & $\begin{array}{l}\text { Decrease blood } \\
\text { vessel proliferation } \\
\text { by binding to VEGF } \\
\text { (prevent interaction } \\
\text { of VEGF with its } \\
\text { receptors Flt-1, KDR) }\end{array}$ & $\begin{array}{l}\text { Bleeding, rash, } \\
\text { gastrointestinal } \\
\text { perforation, allergic } \\
\text { reactions, increased risk } \\
\text { of infections }\end{array}$ \\
\hline Cetuximab & Erbitux (2004) & $\begin{array}{l}\text { EGFR-expressing } \\
\text { metastatic } \\
\text { colorectal } \\
\text { carcinoma }\end{array}$ & $\begin{array}{l}\text { Chimeric } \\
\text { lgG1 }\end{array}$ & $\begin{array}{l}\text { Bristol-Myers } \\
\text { Squibb (USA), } \\
\text { Merck (EU) }\end{array}$ & $\begin{array}{l}\text { Inhibit cell growth, } \\
\text { induct apoptosis, } \\
\text { reduce production } \\
\text { of VEGF, by binding } \\
\text { to epidermal growth } \\
\text { factor receptors }\end{array}$ & $\begin{array}{l}\text { Acne-like rash, } \\
\text { photosensitivity, } \\
\text { hypomagnesemia, } \\
\text { infusion-related } \\
\text { reactions }\end{array}$ \\
\hline $\begin{array}{l}\text { Gemtuzumab } \\
\text { ozogamicin }\end{array}$ & Mylotarg (2017) & $\begin{array}{l}\text { CD-33 positive } \\
\text { acute myeloid } \\
\text { leukemia (AML) }\end{array}$ & $\begin{array}{l}\text { Humanized } \\
\text { lgG4 }\end{array}$ & $\begin{array}{l}\text { Wyeth } \\
\text { Pharms Inc. }\end{array}$ & $\begin{array}{l}\text { CD-33 directed } \\
\text { antibody-drug } \\
\text { conjugate }\end{array}$ & $\begin{array}{l}\text { Hepatotoxicity, } \\
\text { haemorrhage, embryo- } \\
\text { fetal toxicity }\end{array}$ \\
\hline Ipilimumab & Yervoy (2011) & $\begin{array}{l}\text { Unresectable } \\
\text { or metastatic } \\
\text { melanoma }\end{array}$ & $\begin{array}{l}\text { Humanized } \\
\text { lgG1 }\end{array}$ & $\begin{array}{l}\text { Bristol-Myers } \\
\text { Squibb }\end{array}$ & $\begin{array}{l}\text { CTLA-4 (Cytotoxic } \\
\text { T-lymphocyte } \\
\text { antigen-4) blocking } \\
\text { antibody }\end{array}$ & $\begin{array}{l}\text { Immune-related } \\
\text { adverse events }\end{array}$ \\
\hline Ofatumumab & Arzerra (2009) & $\begin{array}{l}\text { CLL (chronic } \\
\text { lymphocytic } \\
\text { leukemia) }\end{array}$ & $\begin{array}{l}\text { Human } \\
\operatorname{lgG1}\end{array}$ & Novartis & $\begin{array}{l}\text { Antibody to CD20 } \\
\text { protein }\end{array}$ & $\begin{array}{l}\text { Respiratory infections, } \\
\text { anaemia, neutropenia, } \\
\text { rash }\end{array}$ \\
\hline Panitumumab & Vectibix (2006) & $\begin{array}{l}\text { Metastatic } \\
\text { colorectal } \\
\text { cancer }\end{array}$ & $\begin{array}{l}\text { Human } \\
\operatorname{lgG} 2\end{array}$ & Amgen & $\begin{array}{l}\text { EGFR binding } \\
\text { antibody }\end{array}$ & $\begin{array}{l}\text { Skin rash, fatigue, } \\
\text { nausea, diarrhoea, fever, } \\
\text { hypomagnesemia }\end{array}$ \\
\hline Pembrolizumab & Keytruda (2014) & $\begin{array}{l}\text { Melanoma, non- } \\
\text { small cell lung } \\
\text { cancer, head and } \\
\text { neck squamous } \\
\text { cell carcinoma }\end{array}$ & $\begin{array}{l}\text { Humanized } \\
\text { IgG4 kappa }\end{array}$ & Merck & $\begin{array}{l}\text { PD-1 (programmed } \\
\text { cell death-1) blocking } \\
\text { antibody }\end{array}$ & $\begin{array}{l}\text { Immune-related } \\
\text { adverse events }\end{array}$ \\
\hline Rituximab & Rituxan (1997) & $\begin{array}{l}\text { CLL (chronic } \\
\text { lymphocytic } \\
\text { leukemia), } \\
\text { CD20-positive } \\
\text { non-Hodgkin's } \\
\text { lymphoma }\end{array}$ & $\begin{array}{l}\text { Chimeric } \\
\text { lgG1 }\end{array}$ & Genentech & $\begin{array}{l}\text { Cell lysis, by binding } \\
\text { to CD20 antigen on } B \\
\text { lymphocytes }\end{array}$ & $\begin{array}{l}\text { Skin rash, low blood } \\
\text { pressure, hair loss, } \\
\text { fatigue, cytokine release } \\
\text { syndrome }\end{array}$ \\
\hline Trastuzumab & $\begin{array}{l}\text { Herceptin } \\
\text { (1998) }\end{array}$ & $\begin{array}{l}\text { HER2-positive } \\
\text { breast cancer }\end{array}$ & $\begin{array}{l}\text { Humanized } \\
\text { lgG1 }\end{array}$ & Genentech & $\begin{array}{l}\text { HER2 (c-erb82) } \\
\text { binding antibody }\end{array}$ & $\begin{array}{l}\text { Nausea, diarrhoea, } \\
\text { cardiac dysfunction } \\
\text { (congestive } \\
\text { heart failure, } \\
\text { cardiomyopathy) }\end{array}$ \\
\hline Avelumab & Bavencio (2017) & $\begin{array}{l}\text { Metastatic } \\
\text { Merkel cell } \\
\text { carcinoma } \\
\text { (MCC) }\end{array}$ & $\begin{array}{l}\text { Human } \\
\text { lgG1 } \\
\text { lambda }\end{array}$ & AMD Serono & $\begin{array}{l}\text { PD-L1 (programmed } \\
\text { death ligand-1) } \\
\text { blocking antibody }\end{array}$ & $\begin{array}{l}\text { Immune-mediated } \\
\text { diseases }\end{array}$ \\
\hline Durvalumab & Imfinzi (2017) & $\begin{array}{l}\text { Locally advanced } \\
\text { or metastatic } \\
\text { urothelial } \\
\text { carcinoma }\end{array}$ & $\begin{array}{l}\text { Human } \\
\text { IgG1 kappa }\end{array}$ & AstraZeneca & $\begin{array}{l}\text { PD-L1 (programmed } \\
\text { death ligand-1) } \\
\text { blocking antibody }\end{array}$ & $\begin{array}{l}\text { Immune-mediated } \\
\text { diseases }\end{array}$ \\
\hline $\begin{array}{l}\text { Brentuximab } \\
\text { vedotin }\end{array}$ & Adcetris (2011) & $\begin{array}{l}\text { Hodgkin } \\
\text { lymphoma, } \\
\text { systemic } \\
\text { anaplastic large } \\
\text { cell lymphoma } \\
(\text { ALCL) }\end{array}$ & $\begin{array}{l}\text { Chimeric } \\
\text { lgG1 }\end{array}$ & $\begin{array}{l}\text { Seattle } \\
\text { Genetics }\end{array}$ & $\begin{array}{l}\text { CD30 antibody with } \\
\text { MMAE (monomethyl } \\
\text { auristatin E), which } \\
\text { disrupts microtubule } \\
\text { network in the cell }\end{array}$ & $\begin{array}{l}\text { Chemotherapy-induced } \\
\text { peripheral neuropathy, } \\
\text { neutropenia, fatigue, } \\
\text { nausea, anaemia, fever }\end{array}$ \\
\hline
\end{tabular}


treatment from $12 \mathrm{~h}$ to several weeks. They vary from maculopapular rash to severe adverse events (Steven Johnson Syndrome, erythema multiforme), and are thought to be primarily T-cell mediated reactions, which explains the delayed onset of such toxicities ${ }^{[15]}$.

Prediction of immune-related adverse events and their prevention are essential milestones for the development of personalised cancer treatment. Pharmacogenetic studies will likely be crucial in the near future to understand individual adverse responses to $\mathrm{mAb}$ treatment and how they can be avoided. In spite of the fact that this problem is very topical for modern medicine, there are currently no published studies that have examined the association between individual genetic variations and the development of adverse reactions to $\mathrm{mAb}$ treatment.

\section{Therapeutic significance of pharmacogenetic study}

Pharmacogenetics is a multidisciplinary research area that aims to predict and personalise modern treatment protocols by understanding the influence of genetic variation on drug efficacy and toxicity. Millions of genetic polymorphisms have thus far been identified in the human genome, many of which can affect pharmacokinetics and pharmacodynamics of antineoplastic drugs ${ }^{[16,17]}$. Understanding these genetic polymorphisms is particularly important in cancer research, as cancer cells possess an increased number of genetic mutations, some of which may influence drug transport, metabolism, toxicity and cellular response ${ }^{[18]}$. For non-mAb cancer treatments, the majority of these polymorphisms lie within genes responsible for drug transport and metabolism, and likely underlie inter-individual differences in drug response $^{[19]}$. Genetic polymorphisms in genes, encoding enzymes TPMT (thiopurine methyltransferase), CDA (cytidine deaminase), and CYP2D6 (cytochrome P450 2D6) can lead to severe changes in the metabolism of non-mAb treatments such as mercaptopurine, azathioprine and tamoxifen respectively, but differ significantly from gene polymorphisms responsible for $\mathrm{mAb}$ metabolism and response ${ }^{[20]}$. Due to the immunological nature of $\mathrm{mAbs}$, their efficacy can be affected by variations in genes responsible for antibody recognition, presentation and metabolism. This review will summarise the existing data concerning the influence of genetic variations on cancer treatment with $\mathrm{mAbs}$.

\section{PART 1. THE INFLUENCE OF GENETIC POLYMORPHISMS ON THE METABOLISM OF MONOCLONAL ANTIBODIES}

All current clinically available $\mathrm{mAbs}$ are IgG (immunoglobulin $\mathrm{G}$ ) proteins, consisting of two heavy chains $(50 \mathrm{kDa})$ and two light chains $(25 \mathrm{kDa})$ composed of constant domains $\left(\mathrm{C}_{\mathrm{H}}\right.$ and $\left.\mathrm{C}_{\mathrm{L}}\right)$ and variable domains $\left(\mathrm{V}_{\mathrm{H}} \text { and } \mathrm{V}_{\mathrm{L}}\right)^{[21]}$ [Figure 1]. The variable regions and $\mathrm{C}_{\mathrm{H} 1}$ domain comprise the Fab, which is specific for the target antigen. Together, $\mathrm{C}_{\mathrm{H}_{2}}$ and $\mathrm{C}_{\mathrm{H} 3}$ comprise the fragment crystallizable region $(\mathrm{Fc})$, which can bind to cell surface receptors present on immune cell populations ${ }^{[22]}$. These membrane proteins known as Fc receptors are expressed on B lymphocytes, natural killer cells, macrophages and play role in the recognition of foreign antigens and neoplasms, as well as the activation of phagocytic and cytotoxic cells ${ }^{[23]}$. The half-life of $\mathrm{mAbs}$ is dependent on their structure: murine $\operatorname{IgG}$ have the shortest half-life of 1-2 days ${ }^{[21]}$. Chimeric IgG halflife is equal to 8-10 days and humanized or fully human half-life is 20-30 days ${ }^{[24,25]}$. This is significantly longer than traditional chemotherapies that possess half-lives ranging from hours (methotrexate) to 1-2 days (doxorubicin) $^{[26,27]}$.

mAbs can be administered via intravenous (IV) infusion or subcutaneous (SC) and intramuscular (IM) injections. Due to the higher risk of infusion-related reactions following IV administration of mAbs, SC and IM are more preferable. Systemic absorption of $\mathrm{mAbs}$ from the injection site is slow, and a maximum concentration is usually reached in 1-8 days after SC or IM injection ${ }^{[28]}$. mAbs are distributed from the blood to tissues via convection, which is determined by the blood-tissue hydrostatic gradient, as well as by the sieving effect of the vascular epithelium ${ }^{[29]}$. Absorption of SC and IM administered mAbs is also dependent 


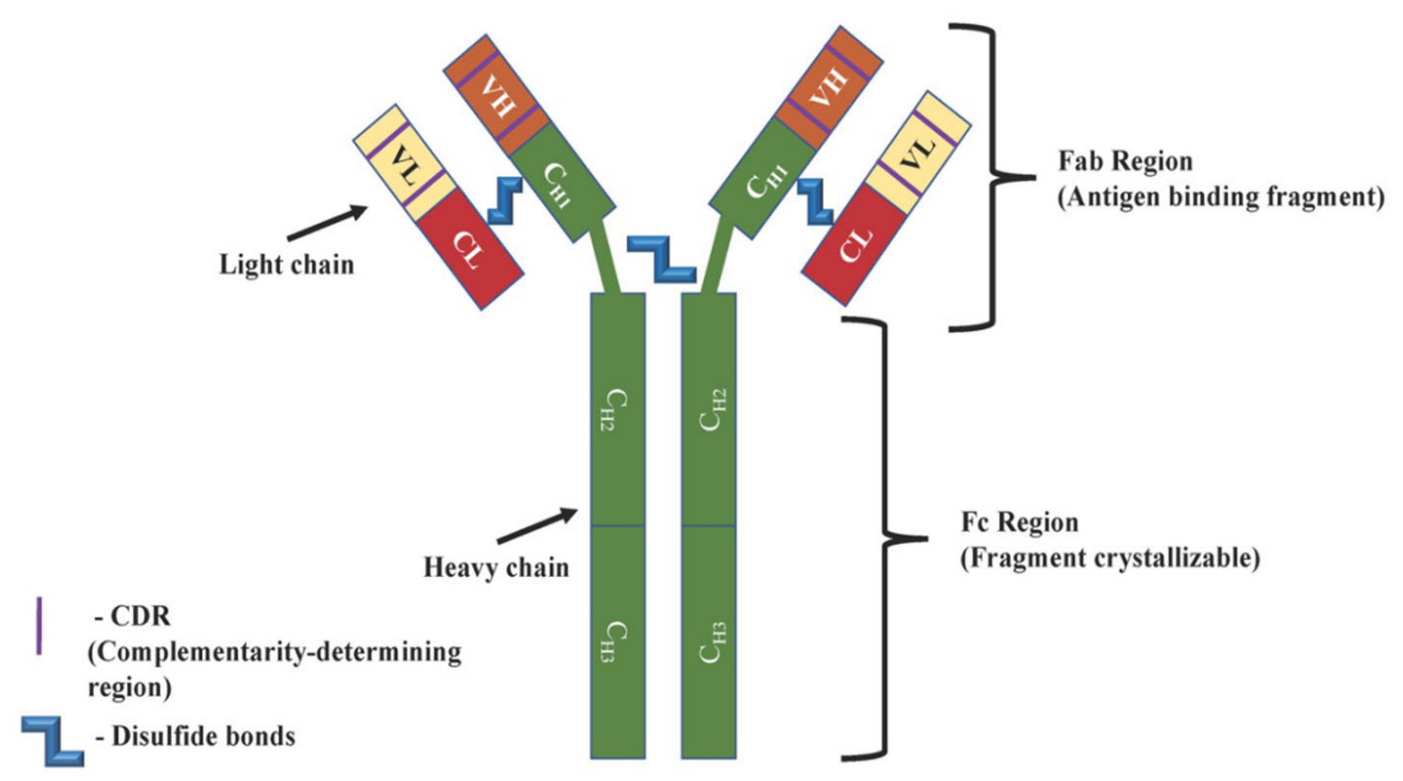

Figure 1. Structure of a monoclonal antibody

on factors such as gender, age, weight, blood pressure, respiratory rate and disease stage, and of course, genetic background $^{[30]}$.

Metabolism of mAbs does not involve the cytochrome P450 enzyme system that is critically important for the hepatic metabolism of many cancer drugs ${ }^{[31]}$. Instead, due to their large molecular size, elimination of $\mathrm{mAbs}$ occurs mostly via endocytosis and pinocytosis followed by proteolytic catabolism ${ }^{[32,33]}$. Moreover, clearance can occur specifically (Fab or Fc receptor binding) or non-specifically ${ }^{[34]}$. Importantly, target mediated clearance is triggered by the interaction of the $\mathrm{mAb}$ with its antigen, and can therefore depend on specific tumour characteristics including the amount of antigen expressed. More frequently uptake of mAbs occurs via receptor-mediated endocytosis in response to binding of the antibody Fc domain to $\mathrm{F} c \gamma \mathrm{R}$ expressed on immune cells, such as monocytes, macrophages, dendritic cells ${ }^{[35]}$. This effect was emphasised in a 2008 study examining a polymorphism in the FcgR3A gene (rs396991 T/G) that results in a change of amino acid phenylalanine (F) to valine (V) at position 158. The valine substitution was shown to increase binding affinity and improve antibody-dependant cell-mediated cytotoxicity ${ }^{[36]}$. As a result, human epidermal growth factor receptor (HER) 2-positive breast cancer patients with the V/V genotype have higher response rate to treatment with anti-HER2 drug trastuzumab ${ }^{[36]}$. This mutation also increases the response rate and progression-free survival (PFS) of patients with colorectal cancer and B-cell lymphoma treated by cetuximab and rituximab, respectively ${ }^{[36-38]}$.

The expression of another Fc receptor termed the neonatal Fc receptor FcRn is also subject to genetic influence based on a variable number of tandem repeats (VNTR) in the promoter region of FCGRT, the FcRn gene. An increased number of tandem repeats has been shown to increase its expression ${ }^{[39]}$, and has subsequently been linked to increased serum infliximab and adalimumab in patients with inflammatory bowel disease ${ }^{[40]}$. As FcRn is responsible for salvaging IgG, reduced expression is thought to result in lower serum concentration and increased clearance via alternative mechanisms ${ }^{[21]}$. This polymorphism was also examined in patients treated with the anticancer epidermal growth factor receptor (EGFR) mAb cetuximab, where VNTR3 homozygotes possessing three repeats demonstrated a reduced distribution, clearance and a trend towards increased half-life $(P=0.058)$ of the mAb when compared to heterozygotes ${ }^{[41]}$. 


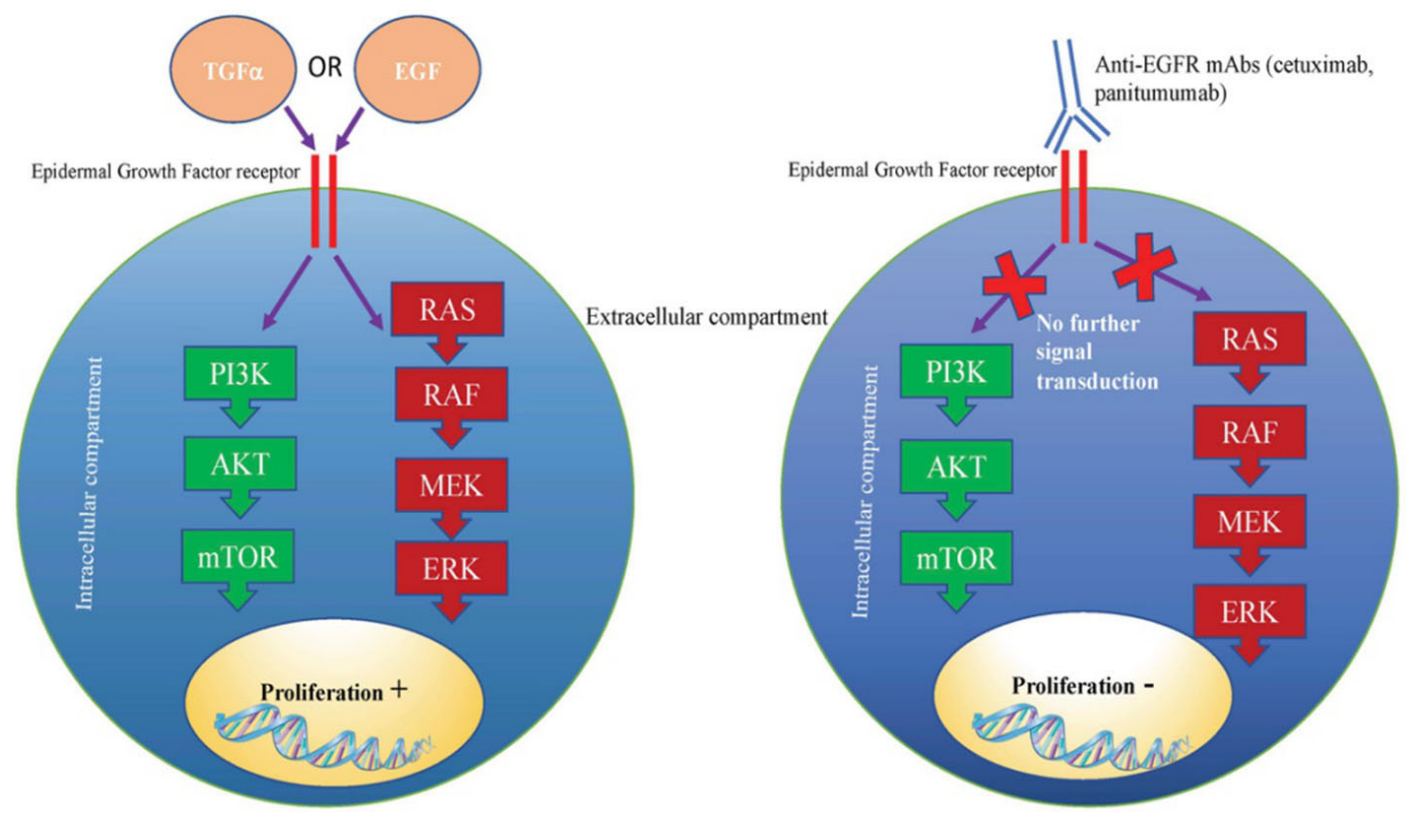

Figure 2. Mechanism of anticancer activity of anti-EGFR mAbs. Cetuximab and panitumumab bind to EGF receptors, thus preventing further signalling transduction via PI3K/mTOR and RAS/ERK pathways. Inactivation of growth signalling pathways prevents cell proliferation and survival. EGFR: epidermal growth factor receptor; mAbs: monoclonal antibodies

\section{PART 2. THE INFLUENCE OF GENETIC POLYMORPHISMS ON MONOCLONAL ANTIBODY TREATMENTS}

\section{Association of growth signalling pathways with monoclonal antibodies response}

Mutations within growth signalling pathway genes are essential to fuel cancer development and progression. One such pathway that is targeted by mAb therapy is the EGFR pathway. Following EGF or Transforming growth factor alpha (TGF $\alpha$ ) binding, EGFR signalling drives metastasis, proliferation and angiogenesis through activation of the Ras/Raf/ERK and PI3K/AKT/mTOR signalling pathways ${ }^{[42]}$. Anti-EGFR mAbs, such as cetuximab and panitumumab prevent receptor-ligand interactions, thus inhibiting downstream activation of growth signalling pathways [Figure 2].

Current pharmacogenetic research approaches have aimed to examine the potential relationship between somatic mutations in the Ras/Raf/ERK and PI3K/AKT/mTOR pathways, with efficacy of anti-EGFR mAbs used for treatment of colorectal cancer (cetuximab, panitumumab). Genetic polymorphisms of the gene encoding Raf protein $(B R A F)$ are very crucial for cancer treatment with anti-EGFR mAbs, with BRAF mutations occurring in $4 \%-11 \%$ of patients with colorectal cancer ${ }^{[43]}$. In particular, BRAFV600E (rs113488022) is associated with an aggressive tumour phenotype, early lymph node metastasis and reduced response to cetuximab and panitumumab treatment ${ }^{[4]}$. A meta-analysis of 10 clinical trials has shown that cetuximab and panitumumab treatment did not improve PFS, overall survival (OS) and response rate in 462 colorectal cancer patients with BRAFV600E mutation (rs113488022) when compared to the control group treated by standard chemotherapy ${ }^{[44]}$. In the same study, Pietrantonio et al ${ }^{[44]}$ have shown that patients without the BRAFV600E mutation were associated with lower risk of progression $(P=0.001)$ and higher response to cetuximab and panitumumab treatment $(P=0.001)$, compared to those with mutation. Interestingly, the $B R A F V 600 E$ mutation has been shown to destabilise the inactive conformation of the Raf protein, rendering the new mutated protein in a constitutively active state ${ }^{[45]}$. Consequently, upstream inactivation of EGFR signalling via $\mathrm{mAb}$ treatment would have minimal therapeutic effect, explaining the clinical findings.

Several studies have examined the correlation between genetic polymorphisms affecting $\mathrm{PI} 3 \mathrm{~K} / \mathrm{mTOR}$ signalling pathway and anti-EGFR mAb treatment. This pathway plays a crucial role in regulating the cell 
cycle. Frequent polymorphisms rs17849079 and rs7640662 within the PIK3CA gene (encoding p110 $\alpha$, the main subunit of PI3K) occur in 10\%-18\% of patients with colorectal cancer and are known as "hotspot mutations" ${ }^{\text {"[46] }}$. A recent meta-analysis confirmed that rs17849079 allele $\mathrm{T}$ and $\mathrm{rs7640662}$ allele $\mathrm{C}$ predict poor objective response rate, lower OS and PFS in patients with metastatic colorectal cancer, treated by cetuximab and panitumumab ${ }^{[47]}$. The PTEN gene, encoding phosphatase and tensin homolog (PTEN) protein is an inhibitor of the PI3K/mTOR pathway, and is strongly linked to a number of cancers. Several studies have demonstrated that PTEN single nucleotide polymorphisms (SNPs) rs701848 allele C, rs2735343 allele G and rs11202586 allele $\mathrm{T}$ are correlated with increased risk of oesophageal squamous cell cancer and testicular germ cell tumours ${ }^{[48]}$, however they have demonstrated no association with response to $\mathrm{mAb}$ treatment to date.

Like other tissues, tumours require adequate vascularisation to proliferate. Vascular endothelial growth factor (VEGF) is a key signalling molecule in this process. The VEGF family consists of 5 members: VEGF-A, placenta growth factor, VEGF-B, VEGF-C and VEGF-D, all of which signal through unique receptors (VEGF receptors). There are three VEGF receptors, VEGFR1, VEGFR2 and VEGFR3, all of which possess unique roles and tissue distribution. Due to its role in angiogenesis however, the majority of cancer research has focused on VEGFR2 and to a lesser extent VEGFR3 for its role in lymphangiogenesis, a crucial driver of cancer metastasis ${ }^{[49]}$. Following VEGFR2 binding, Ras-ERK and PI3K-AKT pathways are activated to stimulate angiogenesis, proliferation and survival ${ }^{[50]}$. VEGF-A and VEGF-C are the key oncogenic drivers within the VEGF family, stimulating angiogenesis and lymphangiogenesis respectively ${ }^{[51]}$. Due to their angiogenic role in tumour formation, the VEGF pathway has become a therapeutic target, as exemplified by anti-VEGF mAbs such as bevacizumab and chemotherapeutic drugs Sunitinib and Sorafenib ${ }^{[52]}$ [Figure 3].

As with EGFR, VEGF genetic polymorphisms can influence individual response to anti-VEGF mAb therapies. In 2008 Schneider and colleagues demonstrated that VEGFA polymorphisms were associated with median OS for the treatment of metastatic breast cancer with bevacizumab ${ }^{[53]}$. In particular, patients with the VEGF rs699947 AA genotype, who were treated by combination of anti-VEGF bevacizumab and paclitaxel chemotherapy had better treatment response and improved OS, as compared to patients treated with paclitaxel only ${ }^{[53]}$. In the case of metastatic colorectal cancer, patients with the rs833061 TT VEGF genotype treated with bevacizumab in combination with folinic acid, fluorouracil and irinotecan showed a reduced risk of $\mathrm{PFS}^{[54]}$. In addition, SNPs rs699947 C>A and rs833061 C>T have both been shown to increase the expression of VEGF protein, and may account for the genotype based differences in anti-VEGF mAb response ${ }^{[55,56]}$.

Mutations in the RAS gene family also affect the response to bevacizumab treatment, where they are present in $30 \%$ of all human cancers ${ }^{[57]}$. In 2016, Fiala et al ${ }^{[58]}$ reported that among 404 Caucasian patients with metastatic colorectal cancer, those with the RAS gene KRAS G12A/V (rs121913529) had lower PFS and OS comparing to patients with KRAS wild-type when treated with bevacizumab. In a group of bevacizumab treated Asian patients with KRAS G12A/V (rs121913529) polymorphism, objective response rate was also lower comparing to patients with wild type tumours ${ }^{[59]}$. Another study showed that among 167 patients who underwent resection of lung metastases for metastatic colorectal cancer, perioperative bevacizumab was correlated with better recurrence and OS in those who had KRAS exon 2 codon 12 mutations ${ }^{[60]}$. The beneficial effect of bevacizumab in patients with a KRAS codon 12 mutation was speculated to be due to its association with VEGF upregulation thus promoting angiogenesis ${ }^{[61]}$. As an inhibitor of VEGF signalling, bevacizumab may inhibit cancers that are reliant on VEGF mediated tumorigenesis ${ }^{[62]}$. The findings relating to treatment outcome eventually translated into clinical practice, with KRAS genotyping becoming an important determinant of EGFR mAb therapy usage ${ }^{[63]}$.

\section{Influence of genetic polymorphisms on the efficacy of immune-checkpoint inhibitors}

A new class of highly effective mAbs known as immune-checkpoint inhibitors have recently come into use that target checkpoint proteins present on T cells. These cell receptors termed CTLA-4 and PD-1 are 


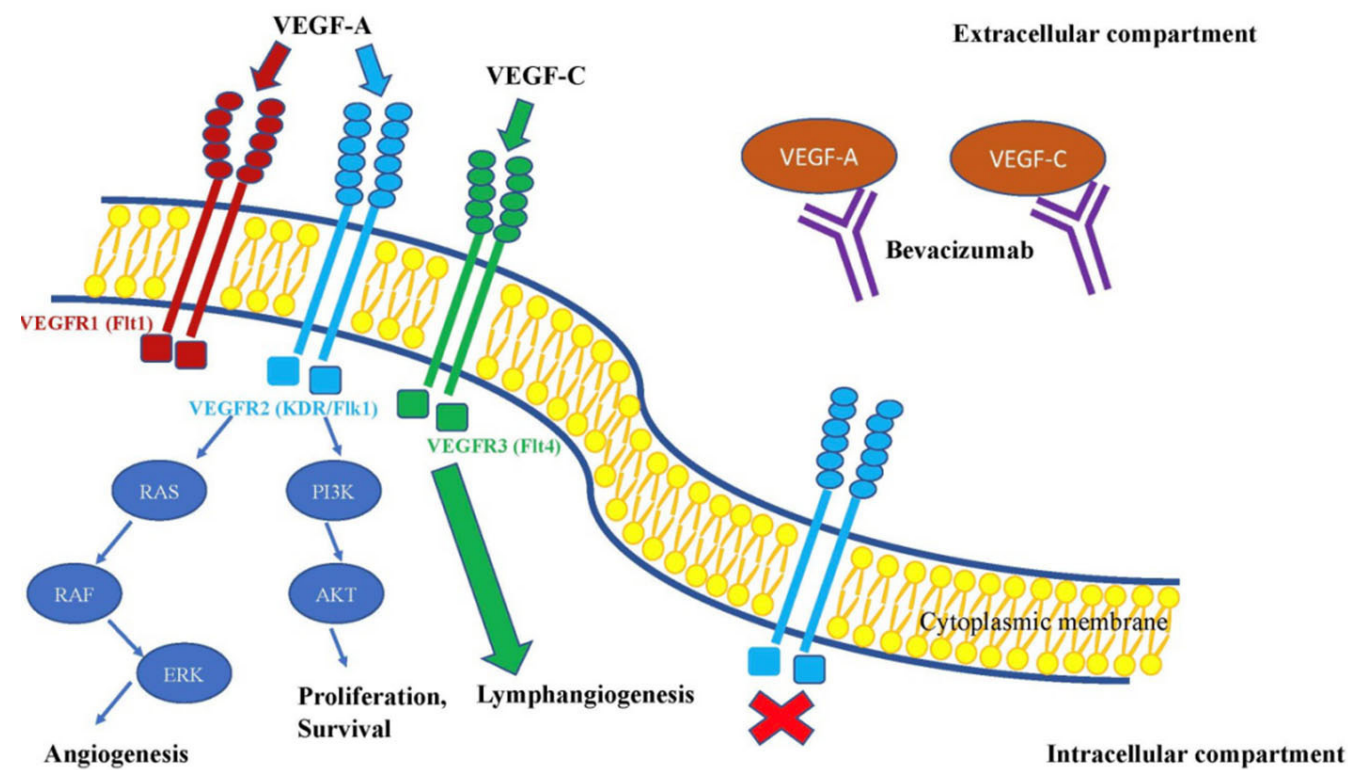

Figure 3. The effect of bevacizumab on VEGF signalling pathway. This figure shows, that bevacizumab is primarily directed to bind VEGF signalling molecules. Such interaction leads to inactivity of VEGF binding to its receptors and as a result it reduces neoangiogenesis. VEGF: vascular endothelial growth factor

regulatory proteins that prevent excessive $\mathrm{T}$ cell responses, but that may become over-expressed in some cancers $^{[64]}$, along with their respective ligands. Cytotoxic T-lymphocyte antigen-4 (CTLA-4) binds CD80 and CD86 on antigen-presenting cells ${ }^{[65]}$ thus downregulating the neoplastic immune responses and facilitating cancer growth $^{[66]}$. Programmed cell death-1 (PD-1) binds PD-L1 and PD-L2 that are often highly expressed on cancer cells ${ }^{[6]]}$. Novel immunotherapies are directed towards blocking CTLA-4 and PD-1, as well as its ligands PD-L1 and PD-L2. These mAbs are highly effective and specific, however they can cause a wide range of adverse events due to a subsequently unregulated $\mathrm{T}$ cell immune response.

SNPs within the PD-L1 gene CD274 have been shown to influence patient response to the anti-PD-1 mAb nivolumab [Table 2]. Patients with non-small cell lung cancer treated by nivolumab possessing the CD274 rs4143815 C/C and C/G genotypes had modestly higher median PFS when compared to patients with the G/ G genotype $(P=0.044)^{[67]}$. In addition, individuals with the $C D 274 \mathrm{rs} 2282055, \mathrm{G} / \mathrm{G}$ and $\mathrm{G} / \mathrm{T}$ genotypes had a modest increase in median PFS compared to T/T carriers $[2.6 \text { months vs. } 1.8 \text { months }(P=0.0163)]^{[67]}$. It has been also suggested in several studies that PD-L1 rs4143815, which is located in the 3' untranslated region (UTR) can influence the expression of PD-L1, thus driving tumour cell immune escape ${ }^{[68-70]}$. In particular, the $\mathrm{C}$ allele of rs 4143815 has been shown to increase production of PD-L1 by attenuating miR-570 ${ }^{[71]}$. Consequently, patients with the rs4143815 C/C genotype have an inferior clinical response to paclitaxelcisplatin chemotherapy ${ }^{[72]}$. While these results contradict some of the work by Nomizo et al ${ }^{[67]}$, it remains undetermined how rs4143815 in particular affects anti-PD-1 therapy. This study was limited by several factors including the small sample size and absence of PD-L1 expression data from tumour cells, and thus, requires further study.

CTLA4 gene polymorphisms are also associated with the response to anti-CTLA-4 treatment. In 2008, Breunis et al. ${ }^{[73]}$ reported that alleles $\mathrm{G}$ of $\mathrm{rs} 4553808$, $\mathrm{T}$ of rs11571317 and A of rs231775 were significantly associated with improved response to CTLA-4 blockade treatment but increased severity (grade III/IV immune-related adverse events) in patients with metastatic melanoma. Moreover, during the haplotype analysis, which included seven SNPs (rs733618, rs4553808, rs11571317, rs5742909, rs231775, rs3087243 and rs7565213), it was suggested that haplotype TACCGGG could be correlated with no response and TGCCAGG with a response to anti-CTLA-4 treatment. However, no statistical significance was detected ${ }^{[73]}$. In 2013, Queirolo et al. ${ }^{[74]}$ examined 6 CTLA-4 SNPs: rs231775 (+49A>G, exon 1), rs4553808 (-1661A>G), 
Table 2. Summary of SNPs' influence on cancer treatment with mAbs

\begin{tabular}{|c|c|c|c|c|}
\hline SNP & Gene & Examined drugs & Type of cancer & Consequences \\
\hline rs699947 (AA) & VEGF & $\begin{array}{l}\text { Bevacizumab (in } \\
\text { combination with } \\
\text { paclitaxel) }\end{array}$ & $\begin{array}{l}\text { Metastatic EGFR-2 negative } \\
\text { breast cancer }\end{array}$ & Higher treatment response and OS \\
\hline rs833061 (TT) & VEGF & $\begin{array}{l}\text { Bevacizumab (in } \\
\text { combination with folinic } \\
\text { acid, fluorouracil and } \\
\text { irinotecan) }\end{array}$ & Metastatic colorectal cancer & Reduced PFS \\
\hline $\begin{array}{l}\text { rs121913529 } \\
(K R A S G 12 A / D)\end{array}$ & KRAS & Bevacizumab & Metastatic colorectal cancer & Reduced PFS and OS \\
\hline $\begin{array}{l}\text { rs } 113488022 \\
(B R A F V 600 E)\end{array}$ & $B R A F$ & Cetuximab, Panitumumab & Colorectal cancer & $\begin{array}{l}\text { Early lymph node metastasis, lower } \\
\text { response }\end{array}$ \\
\hline rs4143815 (CC) & $P D-\angle 1$ & Nivolumab & Non-small cell lung cancer & Higher PFS \\
\hline $\begin{array}{l}\text { rs4553808 (G) } \\
\text { rs11571317(T) } \\
\text { rs231775(A) }\end{array}$ & $C T L A-4$ & Ipilimumab & Metastatic melanoma & $\begin{array}{l}\text { Higher response, associated with } \\
\text { grade } 3-4 \text { immune-related adverse } \\
\text { events }\end{array}$ \\
\hline rs2282055 (GG) & $P D-\angle 1$ & Nivolumab & Non-small cell lung cancer & Higher median of PFS \\
\hline rs396991 (G) & $F C g R 3 A$ & $\begin{array}{l}\text { Trastuzumab } \\
\text { Cetuximab } \\
\text { Rituximab }\end{array}$ & $\begin{array}{l}\text { HER-2 positive breast cancer } \\
\text { Colorectal cancer, } \\
\text { B-cell lymphoma }\end{array}$ & $\begin{array}{l}\text { Higher response rate } \\
\text { Increase response rate and PFS }\end{array}$ \\
\hline rs733618 (G) & $C T L A-4$ & Ipilimumab, Tremelimumab & Metastatic melanoma & Higher response rate \\
\hline rs4553808 (G) & $C T L A-4$ & Ipilimumab & Metastatic melanoma & $\begin{array}{l}\text { Higher risk of endocrine immune- } \\
\text { related adverse events }\end{array}$ \\
\hline $\begin{array}{l}\text { rs733618(G) } \\
\text { rs3087243(G) }\end{array}$ & $C T L A-4$ & Ipilimumab & Metastatic melanoma & $\begin{array}{l}\text { Higher long-term survival at } 3-4 \\
\text { years, comparing to heterozygous }\end{array}$ \\
\hline $\begin{array}{l}\text { rs17849079 (T) } \\
\text { rs7640662 (C) }\end{array}$ & PIK3CA & Cetuximab, Panitumumab & Metastatic colorectal cancer & $\begin{array}{l}\text { Poor objective response rate, lower } \\
\text { OS and PFS }\end{array}$ \\
\hline
\end{tabular}

SNPs: single nucleotide polymorphisms; PFS: progression-free survival; OS: overall survival

rs5742909 (-319C $>\mathrm{T}$, promoter), rs11571316 (-1577G/A), rs11571317 (-658C >T, 5'UTR) and rs3087243 (CT60G $>A$, 3'UTR) in 14 patients with metastatic melanoma treated with ipilimumab or tremelimumab. It was detected that $83 \%(5 / 6)$ of responders possessed the rs733618 G genetic variant of CTLA-4 gene ${ }^{[74]}$. It was also reported, that all responders had diplotype GG - AA (-1577G/CT60G and -1577A/CT60A). In addition, the rs3087243 heterozygous of CTLA-4 gene was correlated with better 5-year survival, compared to patients with homozygous genotype $(P<0.001)$. In this study, all other CTLA-4 SNPs were not statistically correlated with response to the treatment or $\mathrm{OS}^{[74]}$. In a more recent study by Queirolo et al. ${ }^{[75]}$, patients with stage IV melanoma, treated by ipilimumab, possessing rs11571316 (-1577G/A) and rs3087243 (CT60G>A) homozygous genotypes had better long-term survival at 3 and 4 years, compared to heterozygous (G/ A) genotypes. Because patients with the homozygous GG genotype possess reduced CTLA-4 mRNA and protein expression, it was suggested that the efficacy of ipilimumab was increased in these individuals ${ }^{[76]}$. In addition, a 2018 study by Queirolo et al..$^{[7]}$, found that the $\mathrm{rs} 4553808(-1661 \mathrm{G} / \mathrm{G})$ was higher among patients with endocrine immune-related adverse events (irAEs) but not cutaneous or gastrointestinal adverse events.

\section{The future of monoclonal antibody therapies: personalised care?}

Current data suggests that mAbs are effective and specific anticancer drugs, however their efficacy and toxicity have demonstrated significant variability due to genotypic differences relating to $\mathrm{mAb}$ recognition, metabolism and cancer signalling. Consequently, next-generation sequencing (NGS) technologies, and particularly whole-genome sequencing (WGS) and whole-exome sequencing (WES) will prove to be invaluable as mAbs become more widely used. While WGS sequences the genome in its entirety (> 95\%), WES sequences only transcribed regions, and is therefore significantly faster and cheaper. Nonetheless, WGS captures significantly more information, as it can identify significant mutations that are not transcribed such as promoter regions. As the cost of NGS decreases, usage will increase, thus allowing the identification of the full range of somatic mutations present in cancerous and non-cancerous tissue, and allowing physicians to decide on the best therapeutic options ${ }^{[78]}$.

A prime example of NGS research into mAb therapies was performed by Rizvi et al. ${ }^{[79]}$, who performed WES on non-small cell lung cancers treated with pembrolizumab. Paradoxically, a higher number of 
nonsynonymous somatic mutations $(n \geq 302)$ resulted in improved efficacy of pembrolizumab treatment, as indicated by a more durable clinical benefit, higher objective response rate (ORS) and PFS $(P=0.02)$. It was demonstrated that an increase in the number of somatic mutations increased the production of $\mathrm{T}$ cellreactive neoantigens. Because these tumour neoantigens are recognized as foreign, they stimulate a stronger T-cell immune response, particularly in combination with anti-PD-1 mAb treatment ${ }^{[79]}$.

\section{CONCLUSION}

In summary, the influence of genetic background on cancer treatment is not limited to chemotherapies. $\mathrm{mAb}$ efficacy and metabolism can be significantly impacted by host genetics, whether it be non-synonymous mutations altering protein structure and function or promoter mutations affecting gene regulation. Host polymorphisms can also affect mAb target binding, thus significantly affecting treatment efficacy. Key mutations within critical signalling pathways can affect overall and progression free survival, as well as treatment response and treatment-related toxicity. Pharmacogenetics is an essential tool to recognise the association between such germline or somatic mutations and efficacy or toxicity of mAbs in cancer treatment. It provides the potential to personalize cancer therapy with mAbs and other chemotherapies with respect to drug choice, drug combination, and dosing. A better understanding of pharmacogenetics in cancer treatment will undoubtedly benefit existing treatment protocols by implementing new genetic screening methods such as NGS into clinical practice prior to treatment initiation. Such screening will allow physicians to predict drug pharmacokinetics and pharmacodynamics, as well as choose the most appropriate $\mathrm{mAb}$ treatment for individualised cancer management.

\section{DECLARATIONS}

\section{Authors' contributions}

All authors made substantial contributions to conception and design of the study and performed data analysis and interpretation.

\section{Availability of data and materials}

Not applicable.

\section{Financial support and sponsorship}

None.

\section{Conflicts of interest}

All authors declared that there are no conflicts of interest.

\section{Ethical approval and consent to participate}

Not applicable.

\section{Consent for publication}

Not applicable.

\section{Copyright}

(c) The Author(s) 2019.

\section{REFERENCES}

1. Scott AM, Allison JP, Wolchok JD. Monoclonal antibodies in cancer therapy. Cancer Immun 2012;12:14.

2. Coulson A, Levy A, Gossell-Williams M. Monoclonal antibodies in cancer therapy: mechanisms, successes and limitations. West Indian Med J 2014;63:650-4.

3. Sgro C. Side-effects of a monoclonal antibody, muromonab CD3/orthoclone OKT3: bibliographic review. Toxicology 1995;105:23-9.

4. Cho A, Haruyama N, Kulkarni AB. Generation of transgenic mice. Curr Protoc Cell Biol 2009; doi: 10.1002/0471143030.cb1911s42. 
5. Hammers CM, Stanley JR. Antibody phage display: technique and applications. J Invest Dermatol 2014;134:1-5.

6. Kurosawa K, Lin W, Ohta K. Chimeric antibodies. Methods Mol Biol 2014;1060:139-48.

7. Liu JK. The history of monoclonal antibody development - progress, remaining challenges and future innovations. Ann Med Surg (Lond) 2014;3:113-6.

8. Scheen AJ. International classification of various types of monoclonal antibodies. Rev Med Liege 2009;64:244-7.

9. Goldenberg DM. Radiolabelled monoclonal antibodies in the treatment of metastatic cancer. Curr Oncol 2007;14:39-42.

10. Baldo BA. Adverse events to monoclonal antibodies used for cancer therapy: focus on hypersensitivity responses. Oncoimmunology 2013;2:e26333.

11. Sallman DA, Macklin E, Ali S, Michaelson J, Barnes JA, et al. Rituximab hypersensitivity reactions (HSR): predictors of recurrent and severe reactions based on severity of reaction, NHL histologic subtype, and burden of disease. J Clin Oncol 2012;30.

12. Weiss RB, Baker JR Jr. Hypersensitivity reactions from antineoplastic agents. Cancer Metastasis Rev 1987;6:413-32.

13. Nitta E, Izutsu K, Sato T, Ota Y, Takeuchi K, et al. A high incidence of late-onset neutropenia following rituximab-containing chemotherapy as a primary treatment of CD20-positive B-cell lymphoma: a single-institution study. Ann Oncol 2007;18:364-9.

14. Le Guenno G, Ruivard M, Charra L, Philippe P. Rituximab-induced serum sickness in refractory immune thrombocytopenic purpura. Intern Med J 2011;41:202-5.

15. Isabwe GAC, Garcia Neuer M, de Las Vecillas Sanchez L, Lynch DM, Marquis K, et al. Hypersensitivity reactions to therapeutic monoclonal antibodies: phenotypes and endotypes. J Allergy Clin Immunol 2018;142:159-70.e2.

16. International HapMap C. The international HapMap project. Nature 2003;426:789-96.

17. Lee NH. Pharmacogenetics of drug metabolizing enzymes and transporters: effects on pharmacokinetics and pharmacodynamics of anticancer agents. Anticancer Agents Med Chem 2010;10:583-92.

18. Yan L, Beckman RA. Pharmacogenetics and pharmacogenomics in oncology therapeutic antibody development. Biotechniques 2005;39:565-8.

19. Ingelman-Sundberg M, Rodriguez-Antona C. Pharmacogenetics of drug-metabolizing enzymes: implications for a safer and more effective drug therapy. Philos Trans R Soc Lond B Biol Sci 2005;360:1563-70.

20. Yong WP, Innocenti F, Ratain MJ. The role of pharmacogenetics in cancer therapeutics. Br J Clin Pharmacol 2006;62:35-46.

21. Ryman JT, Meibohm B. Pharmacokinetics of Monoclonal Antibodies. CPT Pharmacometrics Syst Pharmacol 2017;6:576-88.

22. Dirks NL, Meibohm B. Population pharmacokinetics of therapeutic monoclonal antibodies. Clin Pharmacokinet 2010;49:633-59.

23. Qiu WQ, de Bruin D, Brownstein BH, Pearse R, Ravetch JV. Organization of the human and mouse low-affinity Fc gamma R genes: duplication and recombination. Science 1990;248:732-5.

24. Ober RJ, Radu CG, Ghetie V, Ward ES. Differences in promiscuity for antibody-FcRn interactions across species: implications for therapeutic antibodies. Int Immunol 2001;13:1551-9.

25. Tabrizi MA, Tseng CM, Roskos LK. Elimination mechanisms of therapeutic monoclonal antibodies. Drug Discov Today 2006;11:81-8.

26. Inoue K, Yuasa H. Molecular basis for pharmacokinetics and pharmacodynamics of methotrexate in rheumatoid arthritis therapy. Drug Metab Pharmacokinet 2014;29:12-9.

27. Yang F, Teves SS, Kemp CJ, Henikoff S. Doxorubicin, DNA torsion, and chromatin dynamics. Biochim Biophys Acta 2014;1845:84-9.

28. Korth-Bradley JM, Rubin AS, Hanna RK, Simcoe DK, Lebsack ME. The pharmacokinetics of etanercept in healthy volunteers. Ann Pharmacother 2000;34:161-4.

29. Baxter LT, Zhu H, Mackensen DG, Jain RK. Physiologically based pharmacokinetic model for specific and nonspecific monoclonal antibodies and fragments in normal tissues and human tumor xenografts in nude mice. Cancer Res 1994;54:1517-28.

30. Keizer RJ, Huitema AD, Schellens JH, Beijnen JH. Clinical pharmacokinetics of therapeutic monoclonal antibodies. Clin Pharmacokinet 2010;49:493-507.

31. Fellner C. Ipilimumab (yervoy) prolongs survival in advanced melanoma: serious side effects and a hefty price tag may limit its use. P T 2012;37:503-30.

32. Berdeja J, Jagannath S, Zonder J, Badros A, Kaufman JL, et al. Pharmacokinetics and safety of elotuzumab combined with lenalidomide and dexamethasone in patients with multiple myeloma and various levels of renal impairment: results of a phase Ib study. Clin Lymphoma Myeloma Leuk 2016;16:129-38.

33. Waldmann TA, Strober W. Metabolism of immunoglobulins. Prog Allergy 1969;13:1-110.

34. Kamath AV. Translational pharmacokinetics and pharmacodynamics of monoclonal antibodies. Drug Discov Today Technol 2016;2122:75-83.

35. Gessner JE, Heiken H, Tamm A, Schmidt RE. The IgG Fc receptor family. Ann Hematol 1998;76:231-48.

36. Musolino A, Naldi N, Bortesi B, Pezzuolo D, Capelletti M, et al. Immunoglobulin G fragment C receptor polymorphisms and clinical efficacy of trastuzumab-based therapy in patients with HER-2/neu-positive metastatic breast cancer. J Clin Oncol 2008;26:1789-96.

37. Trotta AM, Ottaiano A, Romano C, Nasti G, Nappi A, et al. Prospective evaluation of cetuximab-mediated antibody-dependent cell cytotoxicity in metastatic colorectal cancer patients predicts treatment efficacy. Cancer Immunol Res 2016;4:366-74.

38. Zhang W, Wang X, Li J, Duan MH, Zhou DB. Fcgamma receptor IIIA polymorphisms and efficacy of rituximab therapy on Chinese diffuse large B-cell lymphoma. Chin Med J (Engl) 2010;123:198-202.

39. Sachs UJ, Socher I, Braeunlich CG, Kroll H, Bein G, et al. A variable number of tandem repeats polymorphism influences the transcriptional activity of the neonatal Fc receptor alpha-chain promoter. Immunology 2006;119:83-9.

40. Billiet T, Dreesen E, Cleynen I, Wollants WJ, Ferrante M, et al. A genetic variation in the neonatal Fc-receptor affects anti-TNF drug concentrations in inflammatory bowel disease. Am J Gastroenterol 2016;111:1438-45. 
41. Passot C, Azzopardi N, Renault S, Baroukh N, Arnoult C, et al. Influence of FCGRT gene polymorphisms on pharmacokinetics of therapeutic antibodies. MAbs 2013;5:614-9.

42. Wells A. EGF receptor. Int J Biochem Cell Biol 1999;31:637-43.

43. Tran B, Kopetz S, Tie J, Gibbs P, Jiang ZQ, et al. Impact of BRAF mutation and microsatellite instability on the pattern of metastatic spread and prognosis in metastatic colorectal cancer. Cancer 2011;117:4623-32.

44. Pietrantonio F, Petrelli F, Coinu A, Di Bartolomeo M, Borgonovo K, et al. Predictive role of BRAF mutations in patients with advanced colorectal cancer receiving cetuximab and panitumumab: a meta-analysis. Eur J Cancer 2015;51:587-94.

45. Wan PT, Garnett MJ, Roe SM, Lee S, Niculescu-Duvaz D, et al. Mechanism of activation of the RAF-ERK signaling pathway by oncogenic mutations of B-RAF. Cell 2004;116:855-67.

46. Xu JM, Wang Y, Wang YL, Wang Y, Liu T, et al. PIK3CA mutations contribute to acquired cetuximab resistance in patients with metastatic colorectal cancer. Clin Cancer Res 2017;23:4602-16.

47. Therkildsen C, Bergmann TK, Henrichsen-Schnack T, Ladelund S, Nilbert M. The predictive value of KRAS, NRAS, BRAF, PIK3CA and PTEN for anti-EGFR treatment in metastatic colorectal cancer: a systematic review and meta-analysis. Acta Oncol 2014;53:852-64.

48. Song DD, Zhang Q, Li JH, Hao RM, Ma Y, et al. Single nucleotide polymorphisms rs701848 and rs2735343 in PTEN increases cancer risks in an Asian population. Oncotarget 2017;8:96290-300.

49. Holmes K, Roberts OL, Thomas AM, Cross MJ. Vascular endothelial growth factor receptor-2: structure, function, intracellular signalling and therapeutic inhibition. Cell Signal 2007;19:2003-12.

50. Sever R, Brugge JS. Signal transduction in cancer. Cold Spring Harb Perspect Med 2015;5:a006098.

51. Kieran MW, Kalluri R, Cho YJ. The VEGF pathway in cancer and disease: responses, resistance, and the path forward. Cold Spring Harb Perspect Med 2012;2:a006593.

52. Meadows KL, Hurwitz HI. Anti-VEGF therapies in the clinic. Cold Spring Harb Perspect Med 2012;2:a006577.

53. Schneider BP, Wang M, Radovich M, Sledge GW, Badve S, et al. Association of vascular endothelial growth factor and vascular endothelial growth factor receptor-2 genetic polymorphisms with outcome in a trial of paclitaxel compared with paclitaxel plus bevacizumab in advanced breast cancer: ECOG 2100. J Clin Oncol 2008;26:4672-8.

54. Bocci G, Loupakis F. Bevacizumab pharmacogenetics in tumor treatment: still looking for the right pieces of the puzzle. Pharmacogenomics 2011;12:1077-80.

55. Cao C, Ying T, Fang JJ, Sun SF, Lv D, et al. Polymorphism of vascular endothelial growth factor -2578C/A with cancer risk: evidence from 11263 subjects. Med Oncol 2011;28:1169-75.

56. Wang K, Liu L, Zhu ZM, Shao JH, Xin L. Five polymorphisms of vascular endothelial growth factor (VEGF) and risk of breast cancer: a meta-analysis involving 16,703 individuals. Cytokine 2011;56:167-73.

57. Adjei AA. Blocking oncogenic Ras signaling for cancer therapy. J Natl Cancer Inst 2001;93:1062-74.

58. Fiala O, Buchler T, Mohelnikova-Duchonova B, Melichar B, Matejka VM, et al. G12V and G12A KRAS mutations are associated with poor outcome in patients with metastatic colorectal cancer treated with bevacizumab. Tumour Biol 2016;37:6823-30.

59. Nakayama I, Shinozaki E, Matsushima T, Wakatsuki T, Ogura M, et al. Retrospective study of RAS/PIK3CA/BRAF tumor mutations as predictors of response to first-line chemotherapy with bevacizumab in metastatic colorectal cancer patients. BMC Cancer 2017;17:38.

60. Renaud S, Schaeffer M, Falcoz PE, Seitlinger J, Romain B, et al. Perioperative bevacizumab improves survival following lung metastasectomy for colorectal cancer in patients harbouring v-Ki-ras2 Kirsten rat sarcoma viral oncogene homologue exon 2 codon 12 mutations. Eur J Cardiothorac Surg 2017;51:255-62.

61. Guerrero S, Casanova I, Farre L, Mazo A, Capella G, et al. K-ras codon 12 mutation induces higher level of resistance to apoptosis and predisposition to anchorage-independent growth than codon 13 mutation or proto-oncogene overexpression. Cancer Res 2000;60:6750-6.

62. Wang Y, Fei D, Vanderlaan M, Song A. Biological activity of bevacizumab, a humanized anti-VEGF antibody in vitro. Angiogenesis 2004; 7:335-45.

63. Lamy A, Blanchard F, Le Pessot F, Sesboue R, Di Fiore F, et al. Metastatic colorectal cancer KRAS genotyping in routine practice: results and pitfalls. Mod Pathol 2011;24:1090-100.

64. Seidel JA, Otsuka A, Kabashima K. Anti-PD-1 and anti-CTLA-4 therapies in cancer: mechanisms of action, efficacy, and limitations. Front Oncol 2018;8:86.

65. Chambers CA, Kuhns MS, Egen JG, Allison JP. CTLA-4-mediated inhibition in regulation of T cell responses: mechanisms and manipulation in tumor immunotherapy. Annu Rev Immunol 2001;19:565-94.

66. Buchbinder EI, Desai A. CTLA-4 and PD-1 pathways: similarities, differences, and implications of their inhibition. Am J Clin Oncol 2016;39:98-106.

67. Nomizo T, Ozasa H, Tsuji T, Funazo T, Yasuda Y, et al. Clinical impact of single nucleotide polymorphism in PD-L1 on response to nivolumab for advanced non-small-cell lung cancer patients. Sci Rep 2017;7:45124.

68. Tan D, Sheng L, Yi QH. Correlation of PD-1/PD-L1 polymorphisms and expressions with clinicopathologic features and prognosis of ovarian cancer. Cancer Biomark 2018;21:287-97.

69. Lee SY, Jung DK, Choi JE, Jin CC, Hong MJ, et al. Functional polymorphisms in PD-L1 gene are associated with the prognosis of patients with early stage non-small cell lung cancer. Gene 2017;599:28-35.

70. Yeo MK, Choi SY, Seong IO, Suh KS, Kim JM, et al. Association of PD-L1 expression and PD-L1 gene polymorphism with poor prognosis in lung adenocarcinoma and squamous cell carcinoma. Hum Pathol 2017;68:103-11.

71. Wang W, Li F, Mao Y, Zhou H, Sun J, et al. A miR-570 binding site polymorphism in the B7-H1 gene is associated with the risk of gastric adenocarcinoma. Hum Genet 2013;132:641-8. 
72. Lee SY, Jung DK, Choi JE, Jin CC, Hong MJ, et al. PD-L1 polymorphism can predict clinical outcomes of non-small cell lung cancer patients treated with first-line paclitaxel-cisplatin chemotherapy. Sci Rep 2016;6:25952.

73. Breunis WB, Tarazona-Santos E, Chen R, Kiley M, Rosenberg SA, et al. Influence of cytotoxic T lymphocyte-associated antigen 4 (CTLA4) common polymorphisms on outcome in treatment of melanoma patients with CTLA-4 blockade. J Immunother 2008;31:58690.

74. Queirolo P, Morabito A, Laurent S, Lastraioli S, Piccioli P, et al. Association of CTLA-4 polymorphisms with improved overall survival in melanoma patients treated with CTLA-4 blockade: a pilot study. Cancer Invest 2013;31:336-45.

75. Queirolo P, Dozin B, Morabito A, Banelli B, Piccioli P, et al. Association of CTLA-4 gene variants with response to therapy and long-term survival in metastatic melanoma patients treated with ipilimumab: an italian melanoma intergroup study. Front Immunol 2017;8:386.

76. Palacios R, Comas D, Elorza J, Villoslada P. Genomic regulation of CTLA4 and multiple sclerosis. J Neuroimmunol 2008;203:108-15.

77. Queirolo P, Dozin B, Morabito A, Banelli B, Carosio R, et al. CTLA-4 gene variant $-1661 \mathrm{~A}>\mathrm{G}$ may predict the onset of endocrine adverse events in metastatic melanoma patients treated with ipilimumab. Eur J Cancer 2018;97:59-61.

78. Kamps R, Brandao RD, Bosch BJ, Paulussen AD, Xanthoulea S, et al. Next-generation sequencing in oncology: genetic diagnosis, risk prediction and cancer classification. Int J Mol Sci 2017;18:E308.

79. Rizvi NA, Hellmann MD, Snyder A, Kvistborg P, Makarov V, et al. Cancer immunology. Mutational landscape determines sensitivity to PD-1 blockade in non-small cell lung cancer. Science 2015;348:124-8. 